\title{
ISLANDSCAPES OF THE AZORES AND MADEIRA IN THE ART OF NUNO HENRIQUE, MARIA JOSÉ CAVACO AND RUI MELO
}

[Received October 22nd 2018; accepted January 29th 2019 - DOI: 10.21463/shima.13.1.08]

\section{Ana Nolasco}

UNIDCOM/IADE, Universidade Europeia, Lisbon <analascosapopt@gmail.com>

\begin{abstract}
This article analyses a number of representations of the islandscapes of the Madeira and the Azores archipelagos. These representations highlight an aspect that is generally outside the framework of the hegemonic continental perspective of the islands: ie the fragility, uncertainty, resilience and imperfection of human existence on them and the local experience and knowledge of their inhabitants. In this study, I raise the following questions: i) in what way can representations of islandscapes contribute to an independent insular imaginary? and ii) what contribution can insular Atlantic criticism offer to the deconstruction of dominant epistemologies? I argue that the works analysed in the article share an archipelagic aesthetic (in that the deconstruction of dominant stereotypes unleashes a poetic impulse that "makes strange" what is otherwise familiar. As such, these works exercise freedom from opacity - vis-a-vis the reductive transparency of insular representation created by well-established continental cultural traditions - thereby contributing to the possibility of the coexistence of different worldviews.
\end{abstract}

\section{Introduction}

Macaronesia (Figure 1) is collective term that refers to the aggregation of the archipelagos of Madeira, Azores, Cape Verde and the Canary Islands. Its name derives from the conjunction of the term makarôn (happiness or fortune) and nesôi (island). As Brito has emphasised, Macaronesia has been a strategic place that has played "a crucial part in the larger political and economic project of the maritime expansion of the Iberian peoples, if not for the entire restructuration of the world-system at large" (2009: 15 - author's translation). At first, these islands offered logistic support to the initial expeditions and, afterwards, to the colonisation that ensued, maintaining the regular routes between the Iberian Peninsula and the colonies and warehouses that used the Atlantic and Indian routes. The volcanic Azores and Madeira archipelagos constitute autonomous regions of Portugal and were uninhabited when the Portuguese colonised them at the end of the 15th Century. The population of both archipelagos is roughly the same (about 250,000), however, the population of the Madeira archipelago (which has two inhabited islands) is concentrated almost exclusively on a single island; Porto Santo - which is primarily a holiday resort - has only about 5,500 inhabitants. On the other hand, in the Azores the population is distributed across nine islands. In addition to this dispersion, the rainy (albeit mild) climate of the Azores and the frequent seismic and volcanic activity on its islands (the last eruption was in 1958) has served to foster a certain isolation. Conversely, the Madeira archipelago, located on the African Continental Plate, with a subtropical climate, has been a tourist destination since the 19th Century, when doctors initially recommended it to patients with tuberculosis.

Shima <www.shimajournal.org> ISSN: 1834-6057 


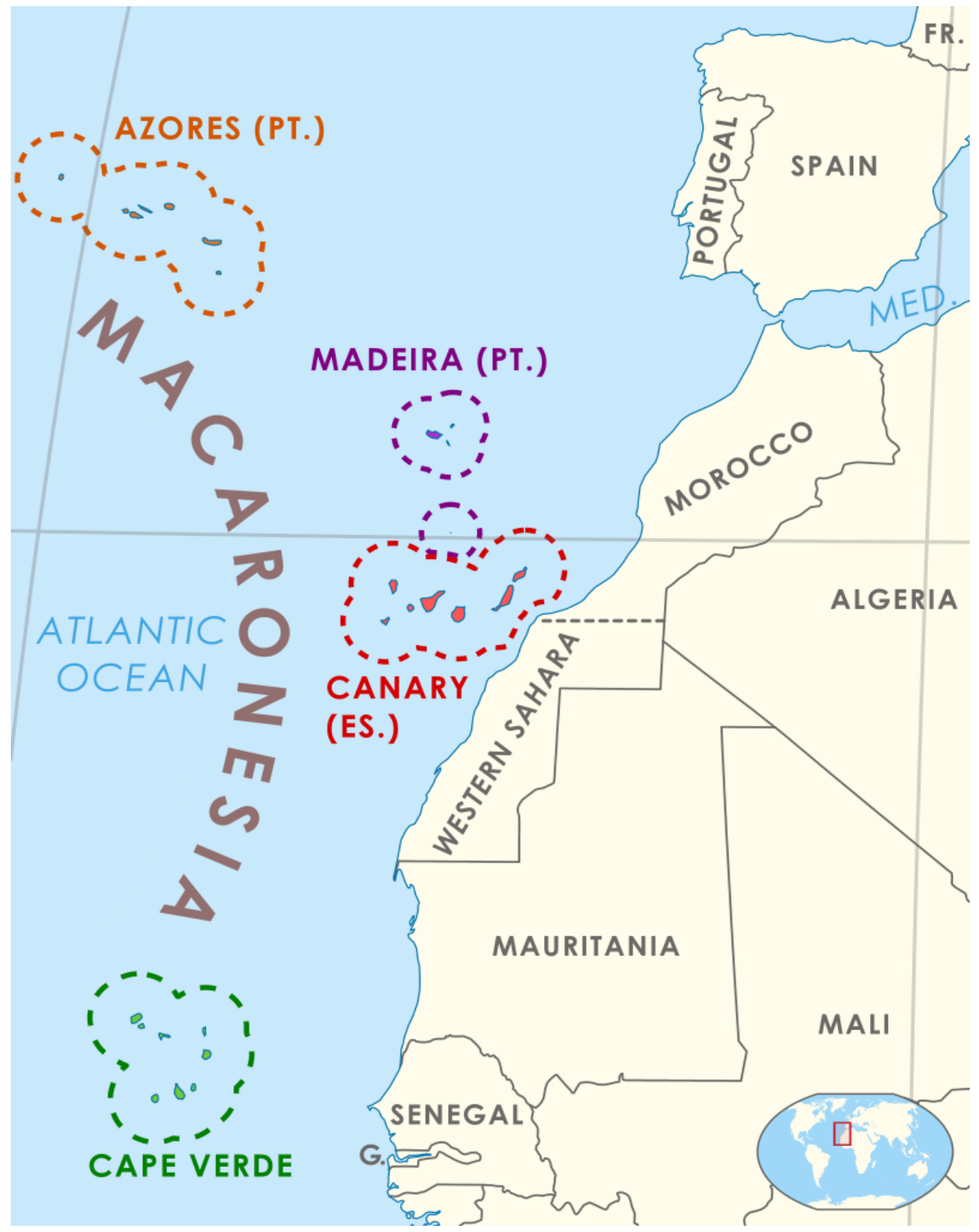

Figure 1 - Macaronesia and the adjacent western coasts of Africa and the Iberian Peninsula (Wikimedia Commons, 2014)

Islands have always been alluring to the human imagination. They represent an exotic place of evasion or a metaphor for the possibility of human renewal, as asserted by Deleuze in Le Îles Déserte (2002). Literature has nurtured this fascination since Antiquity, for example, Atlantis, mentioned by Plato in his Dialogue of Timaeus and Critias (428?-347? BCE); the numerous islands that make up the stages of Ulysses' return to Ithaca (c. 8th-7th Century 
BCE]); Ilha dos Amores, an episode in Camões' epic poem Os Lusíadas (1572); Moore's Utopia (1516); Dafoe's Robinson Crusoe (1719) and Huxley's The Island (1962), among others. This somewhat solipsistic view has been criticised by some postcolonial thinkers, such as Césaire (1950) who drew attention to the fact that islands were twice colonised by Western continental societies. This happened not only physically, since colonisation often lead to the extinction of endogenous species and local populations' modes of existence; but also, mentally, through their fetishisation as passively exotic. In this context, several authors have rewritten Robinson Crusoe in novels such as Pantomime (Walcott, 1978) and Foe (Coetzee, 1986), the latter transforming it into a meta-narrative that reflects on colonial discourses. In a similar attempt at epistemological decolonisation, a new discipline emerged at the end of the 2oth Century: Island Studies which, as noted by one of its founders, McCall, focuses on "the study of islands on their own terms" (1994: 2).

Unlike in the literary tradition, where islands have always held a privileged place in the Western symbolic imaginary, in the visual arts it was only with the development of landscape painting in the 18 th Century, linked to the loss of the notion of nature as "home" (ecos), that the representation of islandscapes gained popularity, above all, as a projection of the exotic. This phenomenon occurred around the same time as James Cook's voyages to South Pacific. During his second voyage (1772-75), Cook was accompanied by the painter William Hodges, who captured in his paintings "the first contact with the other as an opportunity to emphasise difference" (Edmond and Smith, 2003: 99-100), at times drawing on the pictorial tradition of Biblical scenes, such as the Jews' flight into Egypt or Moses crossing the Red Sea. However, pictorial representations of islandscapes cannot be properly understood without contextualising them within the framework of the concept of landscape and its corresponding representation in the visual arts, the origin of which is closely linked to the Renaissance ideal of knowledge and the mastery of reason. The German term landschaft was first used by the Dutch in the 15th Century to describe the pictorial representation of the countryside (Salgueiro, 2001: 38 ). The term was later introduced to England, maintaining a certain ambiguity between landscape as a geographical space within nature and landscape as landscape painting. In the Romance languages, the first recorded use of the term paesaggio also dates from 1521, when it described Flemish works representing nature (ibid).

The Renaissance led to the secularisation of society and the transposition of God - an omnipresent power functioning as a reference of value - to man (ie white, males) through his upright position on the earth, evidenced in the line of the horizon and Euclidean space. In this way, the landscape genre was, from its inception, implicated in a power structure based on the primacy of the Western gaze, mirroring another structure which defined vertical and horizontal coordinates in accordance with a dichotomic logic: nature. Mother Earth - symbol of the irrational realm of instinct - was associated with the (alleged) passivity of woman, imprisoned by the gaze; the subject - male, Western - was identified with the action which imprisons.

It was a long time before landscape gained autonomy as an artistic genre. The first independent representations of landscapes, not linked to another subject, article of decoration or illuminated manuscript, were private pieces conceived in small dimensions. It was only with Albrecht Altdorfer (1480-1538) that the first paintings without human figures began to appear, paintings in which the only subject is the landscape, inaugurating a tradition of landscape painting that would be developed above all in the Netherlands from the mid-16th Century onwards. In the century that followed, a kind of Arcadian beauty was promoted by Claude Lorrain (160o-1682), who, it is safe to say, changed the way in which his 
contemporaries viewed nature, setting the benchmark for ideal landscapes which would later be used as a template by landscape architects in order to compose their gardens like paintings.

The pictorial representation of actual islands ${ }^{1}$ as the incarnation of the exotic was started by Gaugin with the paintings he produced between 1891 and 1893 during his journey to Tahiti, such as 'Parahi-Te Marae' (1892). The topos of the island as a paradise or a place of refuge has since been exploited by the tourist industry which appropriated the iconography established by Gauguin, as have, more recently, the landscapes of Haitian painters JeanClaude Blanc (1965) and Harold Sant-Jean (1959), among others. In this respect, until the end of the 2oth Century, the Azores maintained a similar situation to Madeira, about which Carlos Valente commented:

generally, the aesthetic values of the majority of the population are still those of the 19th Century, and Madeira, which continue to "sell landscapes" because it is what tourism has demanded over the course of this century. The situation is dominated by buyers of landscapes and "views of Funchal", mostly tourists, for whom the acquisition of a painting is part of the list of souvenirs to buy. (1999: 153 - author's translation).

As Suwa (2007) points out, islanders' experience and perception of islands are mediated by cultural and iconographic representations of those same islands that influence perception in a profound way. This article seeks to analyse several representations of the islandscapes of the Azores and Madeira archipelagos that do not condescend in the picturesque manner generally associated with the iconography of islands. To this end, I have selected some works that - in contrast to the fetishised image of the island "frozen in time" as an escape/paradise - focus on processes to rather than the finished product. In this regard, they involve the constant reconstruction of subjectivity, as in Maria José Cavaco's 'Rotas de todos os dias' ('Routes of every day') (Figures 2 and 3); the freedom given to the natural movement of materials in the creative process behind Rui Melo's 'Paisagens Transversais' ('Cross Landscapes') series (2016) (Figures 4, 5 and 6); or the emphasis placed on moments of transition between presence and absence, forgetting and memory, in Nuno Henrique's 'Quarenta Calcos' ('Forty Decals') (2010) (Figures 7 and 8) and the 'Dragoal/Pico Castelo series' (2018) by Nuno Henrique (Figure 9). Although the artistic contexts of the Madeira and the Azores archipelagos differ, artists Rui Melo (b. 1973, Angra do Heroísmo, Azores), Maria José Cavaco (b. 1967, Ponta Delgada, Azores) and Nuno Henrique (b. 1982, Funchal, Madeira) have shared similarly experimental paths.

A resident of Ilha Terceira (Azores), Melo has mainly exhibited his work in the Azores, and, on occasion, in continental Portugal and at international events, and his works also feature in a range of both national and international collections. Cavaco, a resident of Ponta Delgada, São Miguel (Azores), has presented a number of individual exhibitions since 1991 and participated in various collective exhibitions, mostly in Portugal and Spain. Her work is featured in the Galeria Fonseca Macedo, in Ponta Delgada, as well as in private and public collections such as those of Arquipélago - Centro de Artes Contemporâneas and the Museu Carlos Marchado in Ponta Delgada. Part of a younger generation, Henrique was born in Funchal, Madeira, and currently lives in New York, where he stayed on after finishing his

\footnotetext{
${ }^{1}$ Here, I am referring to the representation of the island within the pictorial genre of landscape, and therefore the representation of a real, although idealised, island. Examples of imaginary islands existed before this, such as Arnold Böcklin's well-known painting 'Isle of the Dead' (1880).
} 
artistic training. His work is displayed in continental Portugal, in Lisbon's Galeria Módulo, and he has participated in various individual and collective exhibitions, primarily in Madeira, continental Portugal, Madrid and New York. While these three artists regularly exhibit their work and have received attention from critics, their work is characterised by its experimental nature and therefore exists on the fringes of commercial art circuits and on the margins of mainstream art.

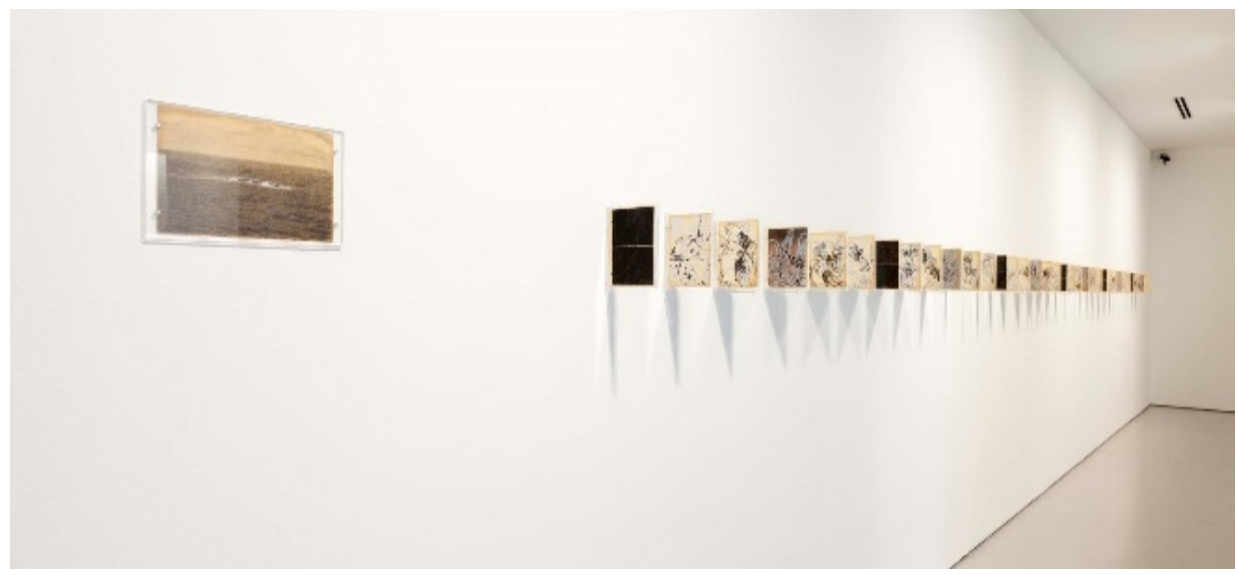

Figure 2 - Maria José Cavaco, 'Rotas de todos os dias' (2010) (photo: Pedro Duarte Jorge).
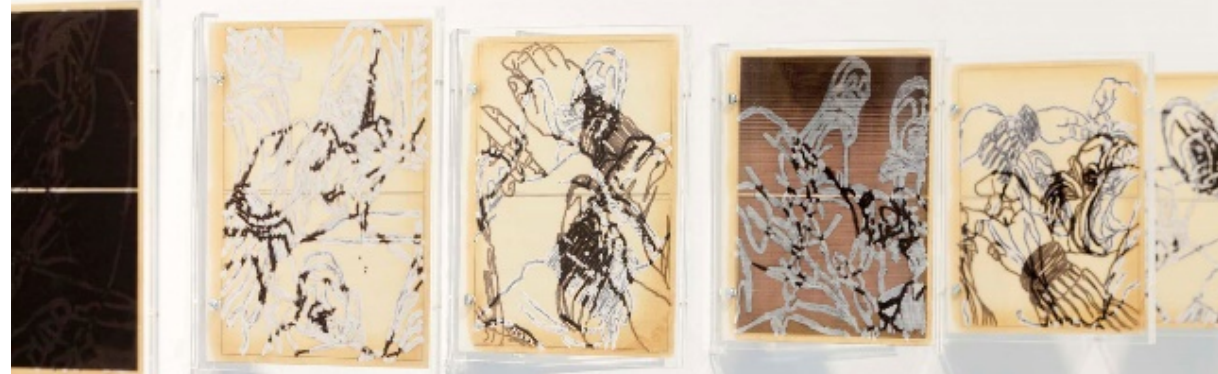

Figure 3 - Maria José Cavaco, 'Rotas de todos os dias' (2010). (Photo: Pedro Duarte Jorge). 


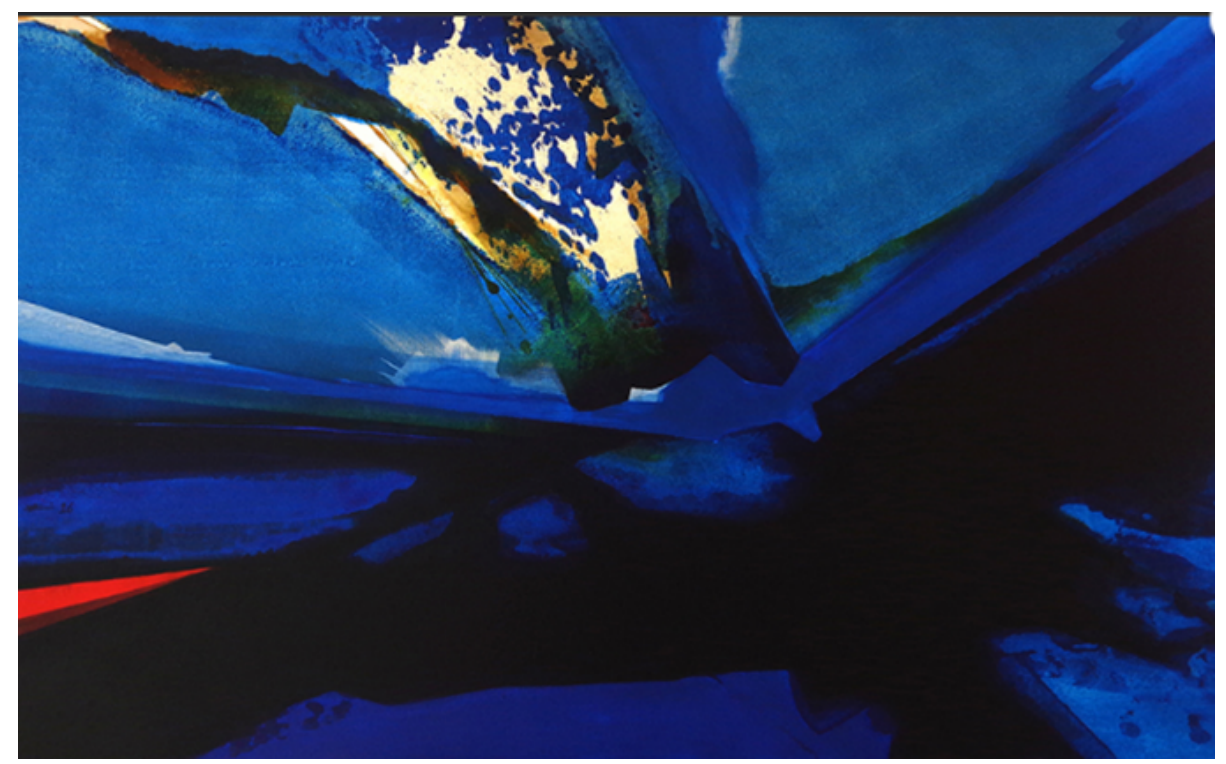

Figure 4 - Rui Melo, 'Paisagem Transversal V' (2016) (courtesy of the artist).

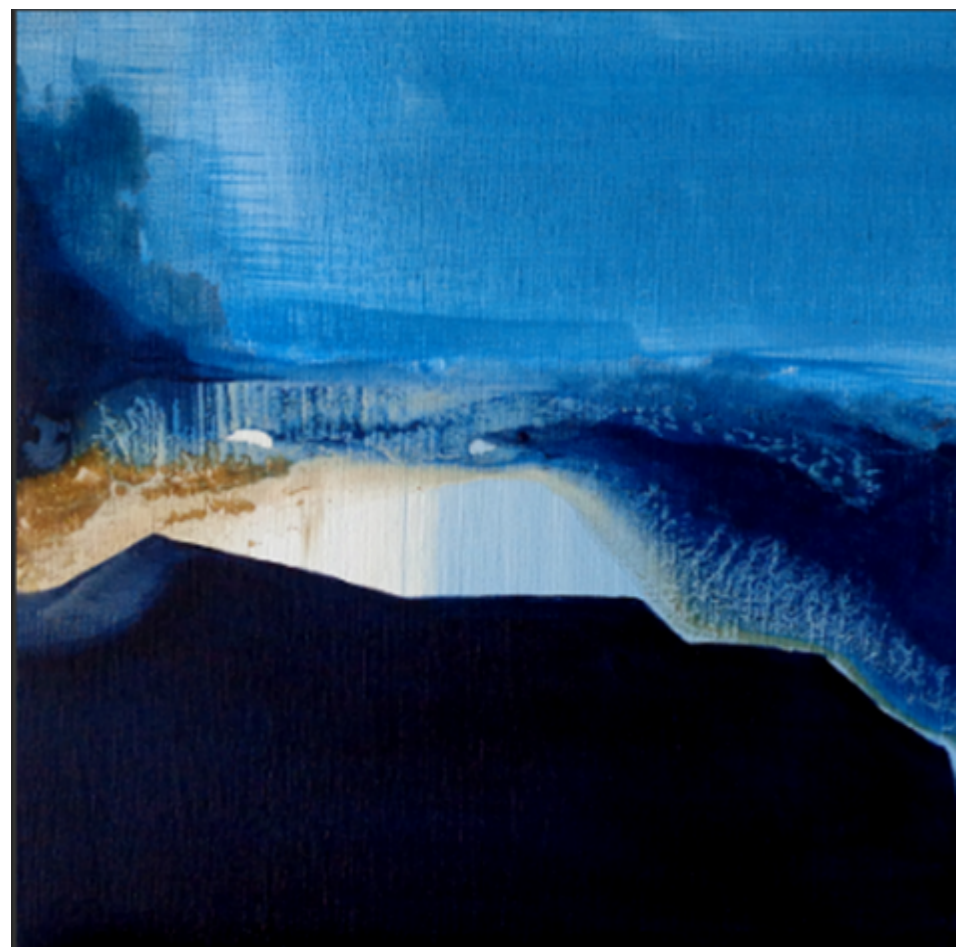

Figure 5 - Rui Melo, 'Paisagem Transversal VIII', 2016 (courtesy of the artist). 


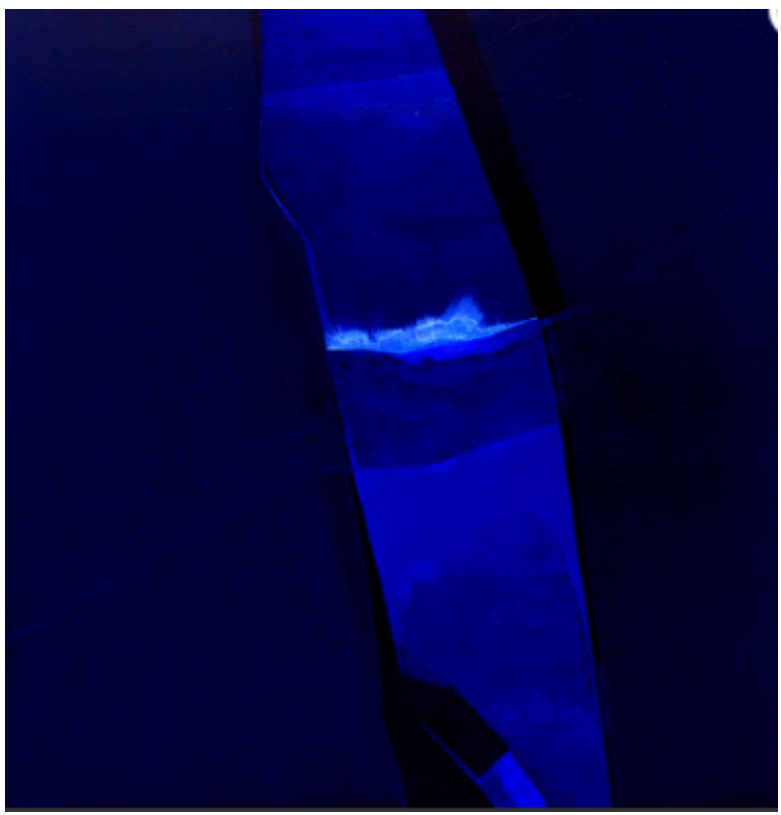

Figure 6 - Rui Melo, 'Paisagem Transversal VI' (2016) (courtesy of the artist).

The pieces chosen for discussion in this article constitute milestones in reflection about the insular landscapes of Madeira and the Azores. Cavaco's 'Rota de todos os dias' is situated on the trajectory of an inter-island dialogue in Macaronesia: it was selected as the representative of the Azores by the organisers of the 'Horizontes Insulares' exhibition, Orlando Britto Jinorio and Nilo Palenzuela. The exhibition sought to "build bridges" (2014: 346) between the islands, which were originally located on the maritime sugar route and share a common "cultural substrate," which, according to Palenzuela (2014), is marked by invasion and displacement and by the dialectic between interior/familiar and exterior/foreign, its main preoccupations therefore standing at the crossroads between the local and the transnational.

Melo's series 'Paisagens Transversais' (2016) (Figures 4, 5 and 6) can be considered to be representative of a more recent generation of artists through its experimental exploration of a phenomenological encounter with the volcanic islands, a reaction to the picturesque vision of the islands manifest in the work of earlier painters such as José Nuno da Câmara Pereira (1937-2018) from the Azores or César Manrique (1919-1992) of the Canaries, whose paintings are prominently marked by the experience of volcanic activity.

Henrique's 'Quarenta Calcos' (2010) (Figures 7 and 8) was initially exhibited as part of the collective exhibition 'Linha de Partida' ('Starting Line') commissioned in 2009 by renowned European art critic Alexandre Melo at the Centro das Artes Casa das Mudas in Calheta, Madeira (a building which was opened in 2004 and has received international prizes for its architecture). The exhibition - which brought together the winners of the five editions of the Henrique and Francisco Franco prizes, hosted through a partnership between the Centro das Artes and Calheta townhall from 1999 to 2007 - proposed, as its title suggests, to launch the careers of a new generation of artists. Henrique won the second prize, as well as 
the fourth in 2005. In his case, it really was a starting point, as the following year he received a scholarship through a partnership between Galeria Porta33 and AR.CO (Escola de Arte Independente) to study sculpture and drawing at the aforementioned school in Lisbon, before moving to New York to complete his artistic training at the Pratt Institute in Brooklyn. For some of the other winning artists, who remained on the island, the exhibition did not live up to expectations. As revealed by interviews, in one way or another, the exhibition indicated a younger generation searching for visibility outside of their home country. The themes of the island, evanescence and memory that run through Henrique's later work are already present in 'Quarenta Calcos' (2010) and reappear, associated with a fictional cartography, in the series 'Dragoal/Pico Castelo' (2018) (Figure 9). In this way, the pieces are located at the intersection of three lines: a rhizomatic line of inter-island dialogue; another, visceral line which passes from the centre of the Earth through the axis of the feet to the reverberation of telluric forces in the body; and a third, transnational trajectory, where the simulacrum makes absence present, and interrogates concepts of value and the relationship between man and the planet.

The recognition of something that is simultaneously familiar and strange to us - which Freud (1919) labelled as unheimlich ('uncanny') - provokes a feeling of strangeness that is reflected upon in Henrique's work through an awareness of oblivion; in Cavaco's through the constant estrangement of the body itself, which in the insular experience is constantly relocated in relation to the horizon (whereas on the mainland the spatial reference is provided by the closer and more stable limit of things rooted on the ground); and in Melo's in terms of the connection with telluric energy.

In this article, I ask how these representations of islandscapes deconstruct stereotypical views of the islands as something fixed and immutable, nurturing an iconography that underlies the narratives of insularity in its most reductive aspect, and examine the extent to which an analysis of these works can disclose an archipelagic aesthetic (Glissant, 1997), developing in a network of simultaneously introspective island processes.

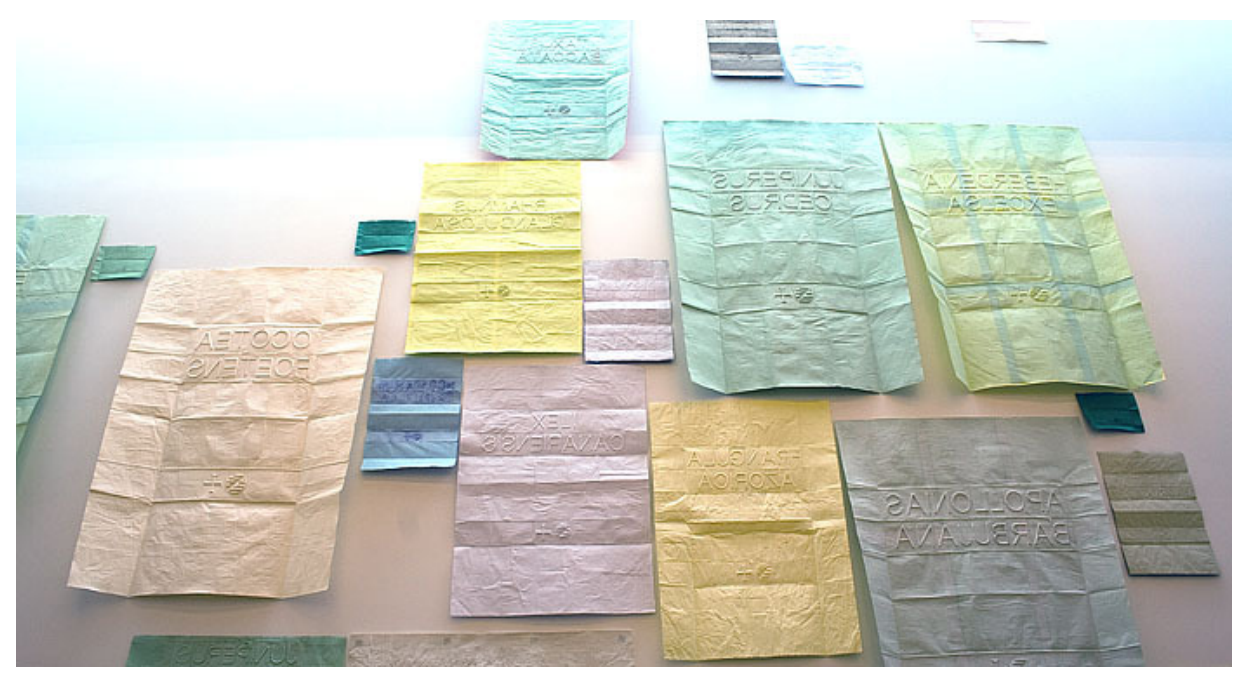

Figure 7 - Nuno Henrique, 'Quarenta calcos' (2009) (courtesy of the artist). 


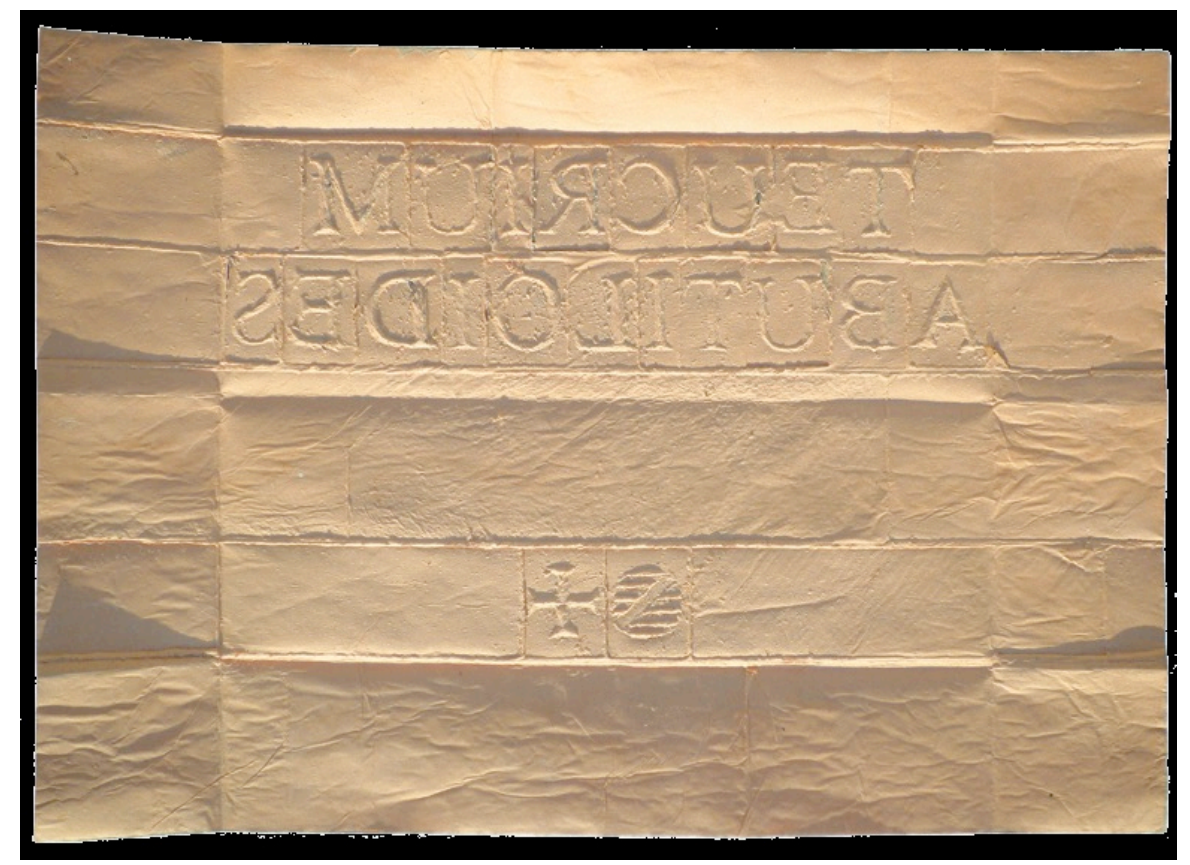

Figure 8 - Nuno Henrique 'Calco 37 Teucrium abutiloides' (2009) (courtesy of the artist).

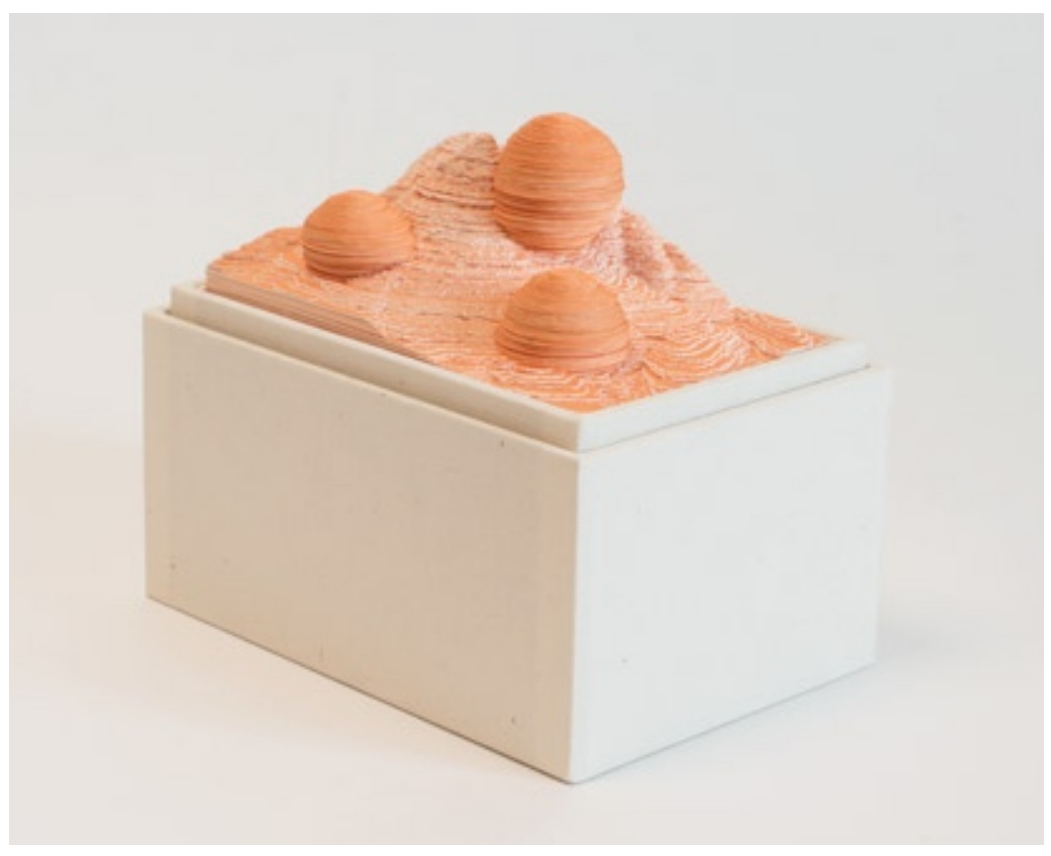

Figure 9 - Nuno Henrique ‘Dragoal/Pico Castelo’ series (2008) (courtesy of the artist). 


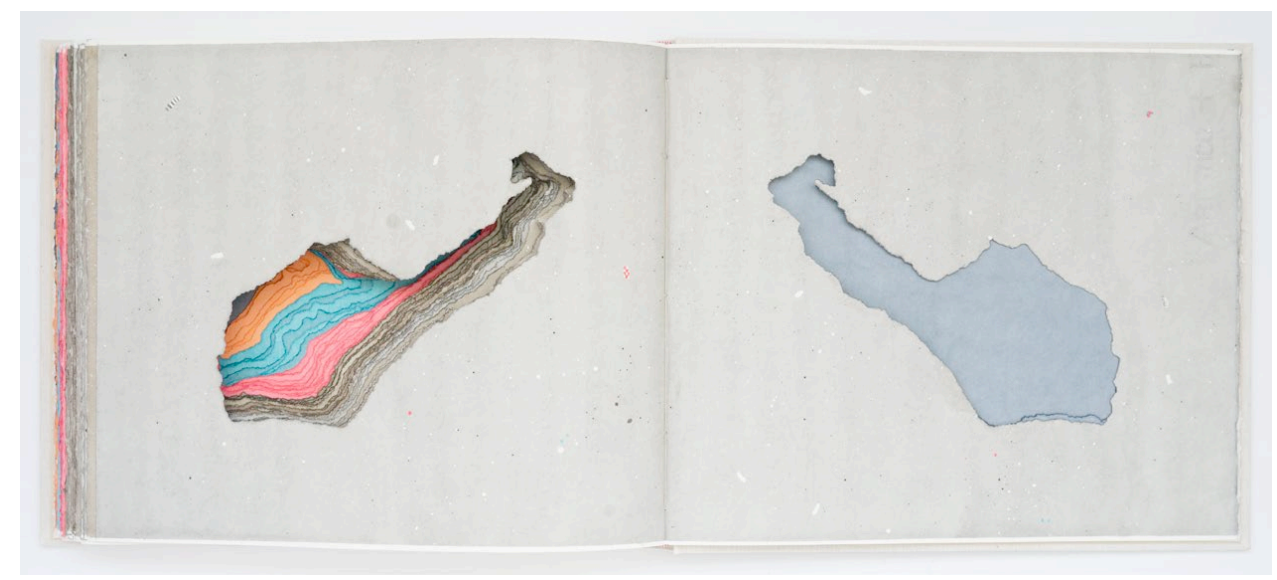

Figure 10- Nuno Henrique “O Ilhéu dos Dragoeiros’ (2018) (courtesy of the artist).

\section{A brief contextualisation of the arts scenes in the Azores and Madeira}

Since 1956, the existence of the Academia de Música e Belas Artes da Madeira (AMBAM) in Madeira has helped to boost the artistic scene on this island. Despite the insularity - or, precisely, in order to resist it - many artists have come together, such as the collectives Art'ilha (1980) and Circul'Arte, (1986) and the artists who created Mail-Art Zine Filigrama (1981) by working with visual poetry and mail art experiences. More recently, since the turn of the millennium, institutional disinvestment, as well as a lack of exhibition spaces, has led to the establishment of alternative art galleries, such as Casa Azul, Representantes de Quarto and Quartos Vagos (which opened in 2002, 2006 and 2007 respectively. At the same time, from the end of the 1980 os and into the early 1990s, some more mainstream art galleries, such as the Gallery Funchália, the Galeria Porta 33 and Galeria Falkenstern Fine Art (which opened in 1989, 1990 and 1991 respectively) have contribute to the dynamisation of the artistic scene.

Among these, Galeria Porta 33 stands out. Madeiran artist and art critic Isabel Santa Clara has identified it as offering "a space for work, meeting and contact with contemporary art with both national and even international visibility, contact which is deepened by the presence of the artists themselves, not only at exhibitions but also at workshops, and by the visits of critics to stimulate the necessary discussions around events" (1993: 76 - author's translation). In this way, the gallery helped create a continuity in the dynamics of the artistic community, overturning the episodic nature of the majority of artistic events that had taken place on the island up until that point (ibid). The gallery has regularly offered artistic residencies to artists in Funchal that have resulted in pieces that mirror the encounter of the artists with the island; such as the video Kitsune (2001) by João Penalva or the series of photos presented in 'When Light Casts no Shadow' (2009) by Edgar Martins. Furthermore, the gallery created a scholarship in order to support the professional development of Madeiran artists. Henrique, for example, received funding from this gallery to study at AR.CO in Lisbon, and from there he then went to New York, where he still resides, to 
continue his artistic training (although he returns frequently to Portugal to exhibit and produce his work).

The lack of higher education institutions catering for art study in the Azores and the dispersion of the population do not facilitate the type of artistic cooperation that occurs in Madeira. Gallery Fonseca Macedo, which opened in 2000 in São Miguel is the only venue to operate consistently after the closure of the Carmina gallery in Terceira (2004-2012), which had some visibility abroad. Nonetheless, the recent opening of Arquipélago - Centro de Artes Contemporâneas by the regional government in 2015 and the creation of the Walk \& Talk festival - which has taken place annually in São Miguel since 2011 and expanded to Terceira in 2016 (as well as other smaller festivals such as Maravilha, launched in 2016), have attempted to overcome the negative effects of insularity by exhibiting Azorean artists' work and attempting to create a critical mass. While most of the artists from the previous generations, such as Daciano da Costa, José Nuno da Câmara Pereira, or Urban, have developed their careers abroad, several artists from more recent generations - such as Carolina Rocha, Vieira Pereira, Catarina Branco, Maria José Cavaco and Rui Melo - have chosen to reside in the archipelago after completing their artistic education abroad.

\section{The Macaronesian islands, their ecologies and cartographies}

The evolution of endemic species in Macaronesia has occurred as a result of inter-island movements and flows between the islands and the mainland, as well as being effected by the global context of neoliberal economic powers and movements of goods and commodities. In the Madeiran context, with its exuberant flora, a number of artists have turned to botanic subjects. In 'O Grande Herbário de Sombras' ('The Great Herbarium of Shadows') (1972), Lourdes Castro,gathers an inventory of 100 shadows of botanical species endemic to the island. More recently, the collaborative work of three artists - Martinho Mendes, Dina Pimenta and Sílvio Cró - was showcased in the retrospective exhibition 'Endemismos e outras Naturezas' ('Endemisms and other natural phenomena') (2014), where they used the botanical metaphor to reflect upon migratory flows, miscegenation processes, the exterior/interior dichotomy, nature/culture and also established an analogy between declines in species and in local crafts skills (which have been diminishing due to the effects of tourism and globalisation) (cf. Salgueiro et al, 2014a: 13).

Henrique, who spent his youth in Madeira, was profoundly affected by the disappearance of about $80 \%$ of the island's laurissilva (indigenous laurel forests) ${ }^{2}$ due to the effects of colonisation. Reports of this phenomenon, such as Frutuoso's Saudades da Terra (1586-1590) - written by a 16th Century historian who described the history and geography of the islands of Macaronesia - or Goethe's Metamorphosis of Plants (1790), among others, had a strong impact on Henrique. Having studied sculpture, he chose fragile materials, such as paper or, more recently, glass; often conceptualising the negative, the absence, the very processes of appearance/disappearance and oblivion/recognition. One of his referents has been the dragon tree (Dracaena Draco), a botanical species native to Macaronesia that is now extinct in the wild.

\footnotetext{
${ }^{2}$ Made up of more than 150 botanical species, many of them unique to Madeira and extinct in continental Europe due to climate change. Madeira is one of the places in the world with the highest plant diversity index per square kilometre. The remaining $20 \%$ plant species that have survived colonisation were declared World Heritage by UNESCO in 1999.
} 
Henrique's installation 'Quarenta Calcos' (2010) (Figures 7 and 8) differs from the works discussed in the previous section since he uses strategies that evoke landscapes, using archaeological and cartographic techniques to create a fictitious landscape that the public must imaginatively (re-)construct. This installation, initially displayed in the Centro das Artes Casa das Mudas in 2009 and subsequently at Galeria Módulo in Lisbon in 2010, consists of 40 paper decals, corresponding to the Latin names of 40 botanical species endangered in Madeira (most of which are also present on the other islands of Macaronesia). Here, the creative process is of fundamental importance. The artist engraved each name on a tombstone, then made the decals using epigraphy. ${ }^{3}$ The inscriptions appear inverted, as in a mirror. Each species was associated with a colour according to its chromatic characteristics and the decals were placed on the walls of the room using hypsometry - a form of spatial representation used in maps in which colour gradation indicates different latitudes. By not displaying the representation of the botanical species, but, rather, the negative impression of their tombstone, the voyeuristic delight, which characterises the landscape genre, is disengaged. At the same time, the artist subverts this traditional pictorial genre, since it presupposes a distance between the spectator's gaze at a sectioned slice of nature.

The picturesque and the sublime were pictorial styles that developed at the end of the 18th and beginning of 19th centuries in the context of landscape painting. The concept of the picturesque was defined by W. Gilpin in An Essay on Prints as "a term expressive of that peculiar kind of beauty which is agreeable in a picture" (1768: 2). In their search for picturesque panoramas, it became popular among nature lovers and artists to use what was known as a 'Claude Lorrain Glass': a small, darkened and slightly convex mirror which allowed the observer to pick out a fragment from nature and confer a certain unity of colour to it. These painters valued the rustic side of nature, as opposed to the harmoniousness of beauty or the tragedy of the sublime, and held up painters such as Lorrain and Nicolas Poussin as their models. The concept of the sublime had wide-reaching repercussions among the Romantics, who favoured landscapes which mirrored the dramatic sentiment of the finite human condition, leading to a kind of representation of landscapes that did not correspond to the classical canon (in which nature was perfectly ordered) and which would have a strong effect on painters such as Gaspar David Friedrich and J.M.W Turner. Having been defined, in the first instance, by Edmund Burke in A Philosophical Enquiry into the Origin of Our Ideas of the Sublime and Beautiful (1757), the concept was later developed by Immanuel Kant in The Critique of Judgment (1790). According to Kant, the sublime is an emotion that enters violently into our imagination that always seeks to synthesise our perceptions into a single whole. He therefore defines the sublime as that "in comparison with which all else is small" (1952: 80). In contrast to the grandeur of the sublime, beneath which lurks the fixed external perspective of the subject, Henrique highlights the vulnerability of nature through the fragility of his materials, undermining the ontological certainty of the real and, simultaneously, the subject through poetic irony.

Vanessa Agnew (2003) has emphasised how the islands, as a conceptual and experimental phenomenon, were crucial to the development of ethnology in the 2oth Century. She uses the example of James Cook's voyages to the Pacific islands in 1772-75, which gave "birth to an ethnology that first compared the natives to each other" (Edmond et al, 2003: 89). The emergence of Anthropology and Ethnology as fields of study played a fundamental role in

\footnotetext{
${ }^{3}$ A technique used in 19th Century archaeology whereby impressions of inscriptions on stone artefacts are obtained since they represent a more reliable form of documentation than drawing.
} 
the construction of taxonomies that underpinned colonial discourses. From the outset, they were instruments of the state, intended to cement its power and to academically legitimise theories concerning the supremacy of races and civilising missions. In this context, the Latin names for the inscriptions in 'Quarenta Calcos' - Latin being a dead language - is noteworthy: both taxonomy and cartography emerged within the scope of the colonisation project. They were used as ideological instruments, dividing territories and legitimising the colonial order. As Henrique observed in an interview with the author in 2017:

Latin is what remains of one of the greatest empires in the world... the names of those species were created in the 19th Century and Latin was the chosen language. Almost all scientific research was always written in Latin, which expresses a desire for an empire. (author's translation)

Considering that dominance is also achieved through language, it is a subtle form of imperialism that covertly transfers a whole set of values, formatting discourses and considering all forms of communication that differ from the dominant one as disposable. Thus, the fragility of paper and the frailty of the inscriptions ironise the longing for an empire, symbolised by Latin, and go against the notion of grandiosity (associated with funerary sculpture) while embodying a self-reflection on the very origin of sculpture.

Cartography is also present in this artist's other works, in which the topology of the island is the starting point, such as his artist's books shown in the exhibition 'O Grande Atlas do Mundo' ('The Great Atlas of the World') (2014), in Galeria Módulo, Lisbon (Figures 10 and 11) or 'O velho Dragoeiro que existia na Ponta do Garajau caiu ao mar durante uma chuvada intensa de sudeste, ocorrida no equinócio de Outono de 1982' ('The old Dragon Tree [Dracaena draco] that existed in Ponta do Garajau that fell into the sea during intense southeastern rainfall that occurred during the 1982 Autumn Equinox') (2010) in Espaço Ilimitado, Porto) (Figure 12). In the latter, paper is overlapped over cut out empty spaces representing the island's coast, thus creating a negative embossing. In the series 'Dragoal/Pico Castelo' presented at the exhibition 'Desconhecem-se montes, encontram-se picos' ('Mountains are unknown, peaks are Found') (2018) in Galeria Módulo, Lisbon), this method was developed in a sculptural technique by using overlapping cut sheets of Fabriano paper, which created small reliefs, therefore evoking the topology of volcanic landscape (particularly, that of Pico Castelo, located on the Island of Porto Santo). These small landscapes were placed inside white cartons and positioned perpendicular to the walls, at the observer's midlevel, a little below eye level. This forms a virtual horizon line, inviting us to approach the artwork and discover what the contents in the boxes can unveil.

The distancing between the referent - the island - and the subject - the islander - is blurred by the creation of landscapes that are both strangely unknown and familiar, thus causing a vague recognition, which Mendonça termed the "game between ignorance and encounter" that underlies the attempt to "fathom ignorance as a possible condition of knowledge" (2018: $\mathrm{np}$ ). According to Ricoeur, it is necessary to plunge into that abyss of emptiness in order to achieve the experience of starting over, without which we could not understand "what it means to continue, to last, to delay, to cease" (2000: 40). But ignorance itself requires a certain degree of knowledge: it is necessary to recognise that the mountains are unknown; it is necessary, at the very least, to have the memory of forgetting. 


\section{Movable horizons}

The islandscapes analysed above deconstruct the insular imagery that frames the gaze on the islands according to certain fixed codes. On the one hand, in Henrique's 'Quarenta Calcos' and the series 'Dragoal/Pico Castelo' (Figures 7, 8 and 9), the illusion of the absence of death, of shadow-less progress, and the very evidence of reality are deconstructed. On the other hand, in Melo's series 'Paisagens Transversais', 2016 (Figures 4, 5 and 6) and Cavaco's and 'Rotas de todos os dias' (2010) (Figures 2 and 3), the primacy of vision and the disembodied observer, fixed in space, are both obliterated.

Cavaco's installation 'Rotas de todos os dias' was presented at the 'Horizontes insulares' exhibition in 2011, which was organised by Nilo Palenzuela and Orlando Britto Jinorio, together with the La Regenta Art Center in Las Palmas, Canary Islands. The installation consists of a set of 101 black graphite drawings on 51 sheets, front and back, placed perpendicularly to the wall. In conversation in 2017, Cavaco referred to these as a "cartography of intersections". This travelling exhibition started with a challenge launched by the organisers to 12 artists and 12 writers from the four constituent archipelagos of Macaronesia (Azores, Madeira, Cape Verde and Canaries) to design a project in which they expressed their island experience and how it relates to the world (Jinorio et al, 2010). These are literal drawings of Cavaco's own body created through direct observation, without the use of mirrors, without techniques to preserve the past (such as mirrors, language or photography) and not including the face. The drawings were created on the front and back of sheets of paper (while taking advantage of the transparency of the sheets) in which the lines that do not overlap are repainted with white-out, leaving a white trace.

The work's starting point was the idea of the horizon, which usually characterises the landscape. The horizon is always present, as Cavaco has pointed out, through both the sea line and how someone on an island perceives space, thus making its subjective territory "extremely vast" (ibid). The contrast between this perception of insular experience and the perception of the island for those who see it from the outside - as something confined within its limits - led the artist to reflect on the islander's body: her/his subjective vision, her/his experiences and memories, as a constant relocation in relation to a point of reference - the horizon. Yet, this is always an unreachable completeness. As the artist observed, the horizon is:

something that maintains the possibility of reference to some kind of unity, but which always recedes, and is also spanned by a reference to incompleteness. Interestingly, I believe that the islander relates to the horizon precisely in this way. The sense of unity will be, say, the possibility of location that the horizon gives us, but that same reference is also the constant reminder of the impermanence of that possibility. Thus, the body of the islander is not something fixed, but a "constant exercise of relocation". (ibid)

As such, Cavaco's 'Rotas de todos os dias' (Figures 2 and 3) implicitly emphasises the sea, which is conceived of not as an absence but as an essential presence in the insular identity, in a manner similar to those concepts advanced by Hau'ofa in 'Our Sea of Islands' (1993) and by Hayward (2012a; 2012b) and Suwa (2012). As noted by Hau'ofa, what can be considered "small" depends largely on that which is excluded or included. Hau'ofa highlights the importance of the sea to the identity of the peoples of Oceania - "Oceania is us. We are the 
sea, we are the ocean" (1993:39) - while also denouncing the reductive conceptualisation of the peoples of Oceania as the inhabitants of a confined terrestrial surface as a form of colonial "belittlement". More recently, due to the fact that the term "archipelago" was excessively associated with terrestrial surfaces and ignored the volumetric space of the sea, Hayward proposed the term aquapelago to designate:

a social unit existing in a location in which the aquatic spaces between and around a group of islands are utilised and navigated in a manner that is fundamentally interconnected with and essential to the social group's habitation of land and their senses of identity and belonging. (2012: 5)

The archipelago of the Azores, made up of nine islands, is just such an aquapelago where the sea is not only essential for survival ${ }^{4}$ but is also, metaphysically, a constitutive element of subjectivity, in the sense of a performative subjectivity re-enacted every day through the sea routes.

Among the artworks placed perpendicularly on the wall in Cavaco's installation we see drawings that reveal a plethora of overlapping body lines (without the white-out) interlacing the feet and hands: the "blind spot" that is the body is, in a way, how the artist sees the world: constantly reconfiguring itself through its movement. Hence, Cavaco outlines possible intersections between the gaze, as seen both from within and from the outside. From the impossibility of reaching the horizon that recedes when we walk (that is, of overcoming time), the impossibility of the self-portrait (witnessed by the absence of the face) also arises. The artist thereby emphasises the permanent relocation of the body and the reinsertion of a subjective vision through the horizon's coordinate which, for the islander, is always somewhere in its landscape's vision. These drawings objectify the gaze, recognising in themselves the horizon's vanishing point, which, according to the artist, constitutes the core of the islander's condition.

I thereby understand 'Rotas de todos os dias' (Figures 2 and 3) as a reflection that develops in an increasingly abstract growth: from the body of the islander to its identity - the portrait; from that to the identity of the islander, in general, and, finally, to a reflection on thought itself. Accordingly, 'Rotas de todos os dias' can be considered as a meta-reflection on the thought itself and the (im)possibility of a single and comprehensive reflection on the status of the islander, thus leaving its representation open-ended.

\section{The Telluric}

In the works discussed in this article - which focus on islanders' relationships with island landscapes - the themes recurrently analysed by Atlantic insular criticism, such as tourism (addressed ironically by artists such as, Ashley Bickerton [a Barbados native, resident in Bali], or Sergio Britto [Canaries]), or by colonialism (which has been questioned by artists such as César Schofield Cardoso [Cape Verde], Marc Latamie [Martinique], or Rigo 23 [Madeira]) - are dealt with indirectly, either explicitly or implicitly. The works thereby avoid the spectator's identification of the islandscape as a place of evasion and fetishisation, as

\footnotetext{
${ }^{4}$ The sea, which permits the circulation and distribution of goods between the islands, as well as fishing (such as tuna fishing, or formerly, whaling) which is vital for the economy, is inherent to the identity of Azoreans. (cf. Neilson et al, 2016: 35-36).
} 
represented in previous generations by the landscape painter Max Römer, who lived in Madeira (1878-196o), or by the Azorean painter Domingos Rebelo (1891-1975), among others. In this context, Rui Melo's series 'Paisagens Transversais' (Figures 4, 5 and 6), displayed in the '30x30' exhibition (2016) in Galeria Acervo, Lisbon, dialogue with Henrique's series 'Dragoal/Pico Castelo', 2018 (Figure 9) and, more directly, with other island artists who reflect telluric presences in their work, such as César Manrique (Canaries), who takes his inspiration from the volcanic landscapes of Lanzarote. Similarly, the Azorean painter emphasises the subjective inner experience, to the detriment of the optical experience, complicit in both the sublime and the picturesque.

The telluric character of the volcanic islands is evident in the series 'Paisagens Transversais,' which reflects its intimate relationship with a strange territory that emerges from the volcanic islands and Ilha Terceira in particular, standing out for the lack of horizon and the submergence into the Earth into things beneath the surface. The exploration of the nuances of the colour material processes - the chance exposure of its irregularities - create a markedly material texture, awakening the senses and affections and evoking a synesthetic perception. In 'Paisagem Transversal VIII' (Figure 5), the decentring of the light source that radiates from the interior points towards an upward blast movement, counteracts the movement from left to right imprinted by the visible traces of the brush. Something new emerges that will replace what was already there and whose collapse is expressed in the descending line of an irregular and shattered contour. Thus, these paintings highlight moments of explosion and rupture in which the elements crumble, intermingle or crack. The sea that surrounds the island is present through the ultramarine blue that predominates almost exclusively in these paintings, except for a few red notes (Figure 4), which can symbolise lava, fire, or blood. They are scintillations of light (Figure 5), autonomous timespaces that emerge (Figure 6) and express the transient, the reminiscences of sensations, and reverberations of the sensitive. Accordingly, they make visible the mute language of things, matter and magma, which is always present beneath the surface, yet hidden from sight.

By refusing a direct link between image and words, the latter works resist the interpretation that seeks to discover what forms represent or what the author's intention is. Instead, these paintings question the concept of rationality, which is based on the pre-existence of the logos and, for this reason, they also question a causal logic between intention and effect which is totally decipherable in words. There are no finished forms in this series, only smears that have neither beginning nor end. In this way, the parts are freed from a subjection to the whole (something that is inherent to the concept of the beautiful organic and the idea of perfection). Instead, they assume the fragment as such, with its irregularity and imperfections. There is no external purpose: the smears of colour are of no use, they are not the decoration of a prior idea, nor matter for filling the form, in the classic platonic sense of hylé e eidos ${ }^{5}$.

5 In Greek, hylé designated the perceptible reality which could be the object of experience; eidos designated "form" or "idea" and was linked to the verb idein, "to see", referring to that which could be seen through mental vision, as opposed to that which could be seen through physical vision, eidolon, which meant image. According to Plato, as exemplified in the allegory of the cavern in Book VII of The Republic, the form eido had ontological precedence over things, as these were mere imperfect reproductions of ideas. In this way, forms and ideas were the ontological essence of things, while perceptible reality, hylé, was an amorphous material that was disposable and superfluous. 


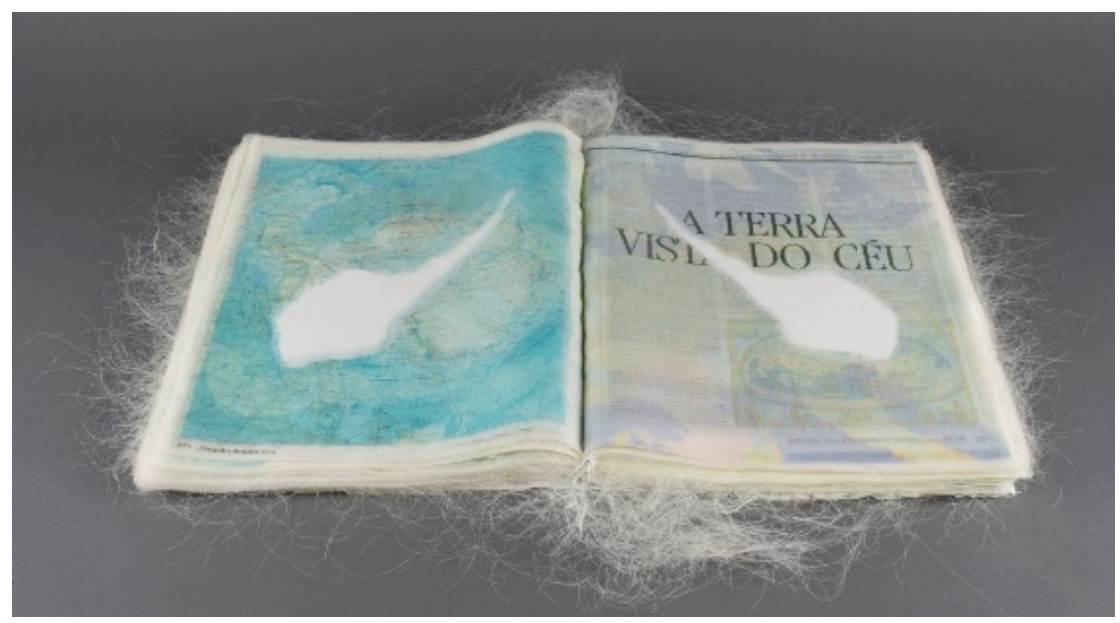

Figure 11 - Nuno Henrique, 'O Grande Atlas do Mundo' (artist's book) (2014) (courtesy of the artist).

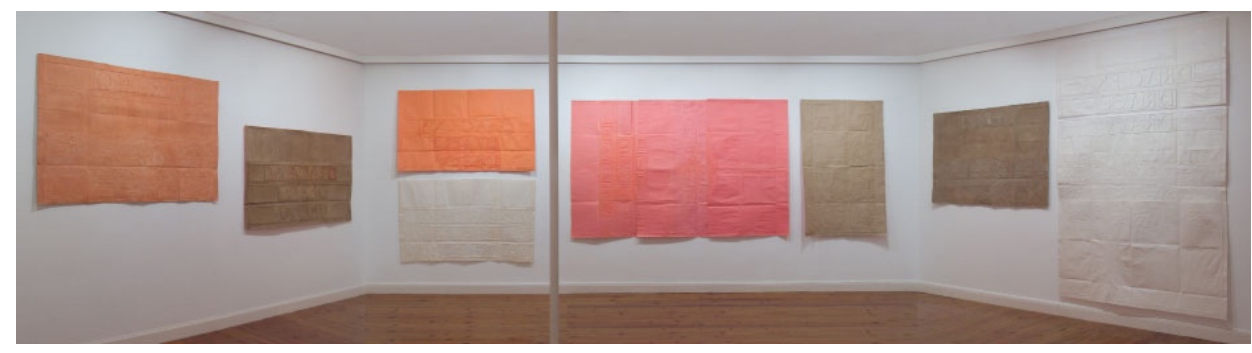

Figure 12 - Nuno Henrique, 'O velho Dragoeiro que existia na Ponta do Garajau caiu ao mar durante uma chuvada intensa de sudeste, ocorrida no equinócio de Outono de 1982' (2010) (courtesy of the artist).

Until the 2oth Century, landscape and portraiture genres were intertwined with the primacy of vision that shaped both nature and the other as something to enjoy. They mirrored a power structure that defined the vertical and horizontal coordinates according to a dichotomous logic from which the criteria of values were ordered. In avoiding a merely visual perception, the series 'Paisagens Transversais' opposes the principal currents of the pictorial landscape tradition: a detachment and perpendicular positioning relative to the ground that allow the picturesque belittling of nature and a distance leading to a voyeurism of the sublime as described by Burke (1998) - an activity that derives its pleasure from the suspension of danger granted by the relative protection of distance.

Melo deconstructs this traditional paradigm. In his paintings, the materials are the ones that speak without being subjected to the will of the painter, spontaneously revealing an agreement analogous to that of nature. As such, they are not "landscapes": the instability of nature is not woven by the artifice of human reason, which seeks to find an order in the entanglement of the threads of nature. In the smears of colour that move in the darkness of a world without gravity or source of external light, matter expresses itself as such. So too does unfathomable nature, the feeling that escapes the fixedness necessary to trade things 
and words between men. Melo's paintings evoke interior landscapes while harnessing the randomness of the development of materials themselves, in a manner that is open to the flow of nature. In these paintings, the border between the natural and the artificial, the subject and the object, are blurred by an understanding of the natural as something that self-produces itself without the intervention of humans. Indeed, because of their different characteristics, the materials expand and interact, thus creating forms that are perceived as landscapes of telluric energy, within a frail and ephemeral balance. Hence, there is an analogy between the pictorial materials, the nature of the telluric matter of the Earth itself, and our senses and faculties, within a natural propensity for synchrony. The symbolic aspect evident in Melo's paintings, in which the artist does not seek to have complete control over his creative process, points to an escape from the traditional paradigm of the West, consistent with an attitude of non-appropriation of nature. As such, through seeking not to dominate the materials of his painting -only to guide their appearance in the medium - he attests to islanders' respect and harmony towards the telluric energies that are an integral part of his own human nature.

\section{Final Considerations - The Strangeness of Islands ${ }^{6}$}

As noted by Palenzuela, "islands are strange or provoke a feeling of strangeness, they are characterised by their oceanic solitude or reveal themselves as the place where the first signs, the first perceptions, the first words germinate" (2006: 90 - author's translation). In his opinion:

The strangeness is related to the most intimate experience of the subject, it could almost be said to be its ineffable experience, born from the very crust of its encounter with the world. And this leads to the status of foreigners in its metaphysical dimension. Feeling estranged is also exiling oneself to an unknown place or to a foreign country. (ibid)

Considered together, the artworks analysed in this article deconstruct the false evidence which assure us of our dominance over things, exposing the uncertainty and fragility of the human condition and, consequently, of human knowledge. All of the pieces provoke a feeling of strangeness, a familiar and unsettling strangeness. Freud defined the unheimlich (uncanny) as something simultaneously strange and familiar, a concept reinforced by the term itself which results from the juxtaposition of two opposites: heimlich, from the word heim - birthplace - an important concept in German culture (expressed by gerborgenheit, a feeling similar to that of the well-being felt by a foetus in the womb); and the prefix un - a negation equivalent to the prefix "un" in English. In this way, these artworks transmit something which is simultaneously particular: the subjective insular experience which cannot be communicated, and something universal awoken by the strangeness of islands: the strangeness of being alive. Palenzuela notes:

Estrangement is therefore the path which leads to alterity: the subject which understands the world or the world which is observed. As a starting point, these

\footnotetext{
${ }^{6}$ The citation taken from the title of a chapter of Las islas extrañas, Nilo Palenzuela (1998), which is itself a citation from a verse by 16th Century Spanish mystic San Juan de la Cruz. (cf. De la Cruz, 2010 $[1622])$.
} 
words - estrangement, strangeness, stranger - bring us before a kind of scenery where it would be possible to explore the insular condition from the only angle which interests me: its universal meaning. (2006: 90)

All of these artists' works implicitly criticise human attempts to dominate Nature, as well as the imposition of a single point of view. Such motives can be found, for instance, in the understated simplicity of Henrique's works, such as 'Quarenta Calcos' or the series 'Dragoal/Pico Castelo' (Figures 7, 8 and 9) - in which the fragility of the paper contrasts with the monumentality of the sculptures; the brittleness of the graphite drawings; in Cavaco's 'Rotas de todos os dias' (Figures 2 and 3); or Melo's in conscientious choice of not manipulating his inks and letting them expand on the surface, thus uncovering the medium. Hence, they manifest an insular Atlantic critique (Adrián, 2014) by deconstructing the notion of contemplation as a form of aesthetic fruition (the cornerstone of Western hegemonic epistemic hierarchies) underlying the most reductive island iconography. The deconstruction of these representations, which reinforce the comfort of an easily digestible gaze in these works, frees a poetic strangeness that I have tried to articulate throughout the text of this article. This poetic claims the right to opacity and the freedom to not understand the other (Glissant, 1996), thus thwarting absorption or appropriation, while favouring coexistence and sharing.

In an epoch of facilitated contact between heterogeneous cultures with differing sensitivities, Glissant believes that his concept of "archipelagos of thought" has the necessary advantage of dealing with subtle differences, of relating to the other through poetry, without restraint. It can, in this way, capture the ambiguity otherwise inconceivable to systematic thought. (Glissant, 1997: 34). From this follow Glissant's relational poetics, created in defence of opacity, of the belief that that which the other is does not need to be transparent to us (a belief that is at the base of any policy of assimilation). Once absorption and appropriation are blocked by opacity, coexistence and exchange are the only forms of connection and relation.

As Glissant asserted in Discours antillais, far from matching up with the artificial notion of a static moment fixed in time, landscape - and in particular the small-scale landscape found in Martinique (1989: xxxviii) - contains a force, "mobile structures" (ibid: 146), that undergo a constant process of transformation, working on the level of duration and collective memory (and not only in the moment in and of individual subjectivity). For Glissant, landscape - the relational interface between nature and the subject - is not a simple backdrop to a story but a player in its own right, in the sense that it is "the deliberated sequence of an always fleeting relationship" (Glissant, 1969: 72) between the subject and nature, the emotional and the objective. In this way, it is the idea of landscape as flux which is emphasised:

The landscape has its language. What is it in our world? Certainly not the immobility of Being, juxtaposed to a relative notion of what I could become, and confronted with an absolute truth that I could reach out for. (1989: 146)

"Archipelagos of thought" have the advantage of working with discourses that are parallel, repeated and fragile. Thinking through these discourses can reveal more elusive, oscillating creative visions, respecting their opacity. As noted by Glissant, there "is no landscape that is not obscure, underneath its pleasing transparencies, if you speak to it endlessly." (Moatamri, 2007: online - author's translation). 
Reflecting the above, he works discussed in this article favour dynamic processes relinquishing a privileged and monolithic position for an unstable and fragile one that, like the rhizome ( $c f$. Deleuze and Guattari, 1980: 36), creates links with neighbouring areas, forging unexpected symbioses. I consider that they share an archipelagic aesthetic that is fluid and in a constant state of self-questioning and is characterised by a "more intuitive, more fragile, threatened way of thinking, yet in accordance with a world in chaos and its unpredictability" (ibid), from which derives the poetics of relation.

These islandscapes are thus fleeting impressions, inward images that escape oral discourse, in which nature is not perceived as something removed from itself, the product of the estranged glance of someone who is fixed in time and space. Accordingly, they do not allow a stereotypical representation of the island, such as a space that lent itself to the dreams of dominion; an object of privileged study - from the colonisers' point of view - for anthropologists and ethnologists; an extension of metaphysical narratives which have been replaced by spaces of evasion and touristic paradises. Despite their diversity, the different approaches of islandscapes that have been analysed here share an emphasis on the empirical dimension and the encounter with that same insular landscape, always unique. However, they are also imbued by the culture in which they stand - the pictorial tradition of the landscape, in Melo's work, science and its different forms of systematisation, in Henrique's, and Cavaco's the philosophical reflection. These works show, as Suwa underlines, that the islanders' gaze on their islands is also woven by memories, as well as the sites' physical and cultural landscape: "Islands are, in this regard, 'cultural landscapes' where imagination takes forms of reality... Islands as works of imagination and as geographical features become a mirror to each other" (2007: 6). As he also characterises islands are "an event" (ibid) - albeit a dynamic one, in constant renewal. Hence, while redeeming the island's own imaginary from the stereotyped representations of the islands, the artworks analysed in this article open space for new approaches stemming from their own terms and creating new and fruitful synergies.

Acknowledgments: Thanks to the Fundação para a Ciência e Tecnologia [FCT], Portugal for the Post-PhD Grant SFRH/BPD/108392/2015 and to my Supervisor, Prof. Dr. Rodrigo Cunha and Co-Supervisor Prof. Dr. Carlos Garrido.

\section{Bibliography}

Adrián, F (2014) ‘Wolfgang Tillman's Still Islands: Photographic Aesthetics of the Margin', Third Text v28 n4: 377-392

Agnew, V (2003) 'Island Encounters and the German Invention of Race', in Edmond, R and Smith, V (eds) Islands in history and representation, New York, Routledge: 81-94

Brito, E (2009) Distância e conexão: insularidade, relações culturais e sentido de lugar no espaço da Macaronésia Angra do Heroísmo: IAC-Instituto Açoriano da Cultura

Jinorio, O and Palenzuela N (eds) (2010) Horizontes insulares-Horizons insulaires, Canarias: Cultura en Red and SEACEX del Gobierno de España, Islas Canarias y Madrid

Burke, E (1998) A Philosophical Enquiry into the Sublime and Beautiful, London: Penguin Classic 


\section{Nolasco: Azores/Madeira Islandscapes in Art}

Camões, L (1978) Os Lusíadas, Porto: Porto Editora

Césaire, A (1950) Discours sur le colonialisme, Paris: Présence africaine

Clara, I (1993) ‘Galeria Porta 33’ Artes e Leilões n22: 75-78

Coetzee, J.M (1986) Foe, London: Penguin

De la Cruz, S (1622) Cántico spiritual, Burgos: Monte Carmelo

Defoe, D (1902) The Adventures of Robinson Crusoe, London: Grant Richards

Deleuze, G (2002) L'ile déserte et autres textes (1953-1974), Paris: Éditions Minuits

Deleuze, G and Guattari, F (1980) Mille plateaux volume 1: Capitalisme et Schizophrénie, Paris : Les Éditions de Minuit

Edmond, R and Smith, V (eds) (2003) Islands in History and Representation, London, New York: Routledge

Freud, S (1919) 'The Uncanny', archived online at: https://web.mit.edu/allanmc/www/freud1.pdf - accessed 28th January 2019

Frutuoso, G (1998) Saudades da Terra, Ponta Delgada: Instituto Cultural

Gilpin, W (1768) An essay on prints: containing remarks upon the principles of picturesque beauty; the different kinds of prints; and the characters of the most noted masters, Cambridge: Cambridge University Press

Glissant, E (1969) L'Intention poétique, Paris: Seuil

----- (1989) Caribbean Discourse, Charlottesville: University Press of Virginia

----- (1990) Poétique de la Relation, Paris: Gallimard

----- (1996) Introduction a une poétique du divers, Paris: Gallimard

----- (1997) Traité du tout-monde, poétique IV, Paris: Gallimard

Goethe, J (2009) The Metamorphosis of Plants, Cambridge: MIT Press

Hau'ofa, E (1993) 'Our Sea of Islands', in Waddell, E, Naidu, V and Hau'ofa, E (eds) A New Oceania: Rediscovering Our Sea of Islands, Suva: University of the South Pacific: 2-16

Hayward, P (2012a) 'Aquapelagos and Aquapelagic Assemblages', Shima: The International Journal of Research into Island Cultures v6 nı: 1-10

---- (2012b) 'The Constitution of Assemblages and the Aquapelagality of Haida Gwaii', Shima: The International Journal of Research into Island Cultures v6 n2: 1-14 


\section{Nolasco: Azores/Madeira Islandscapes in Art}

Homer (1974) Iliad, New York: Anchor Press

Huxley, A (1962) The Island, London: Chatto \& Windus

Kant, I (1952) The Critique of Judgment, Oxford: Clarendon Press

Lombardo, G (2003) A Estética Clássica, Lisboa: Estampa

McCall, G (1994) 'Nissology: a proposal for consideration', Journal of the Pacific Society v6364 n17: 93-106

Mendonça, T (2018) 'Desconhecem-se montes, encontram-se picos' [(unpaginated room sheets), Lisbon: Galeria Módulo

Moatamri, I (2007) 'Poétique de la Relation: Amina Saïd et Édouard Glissant', Trans-3: http://trans.revues.org/18o - accessed 26th January 2019

More, T (1928) Utopia with the dialogue of comfort, London: Ernest Rhys

Neilson, A, Pato, C.B, Gabriel, R, Arroz, A.M, Mendonça, E and Picanço, A (2016) 'In the Azores, looking for the regions of knowing', Island Studies Journal v11 nı: 35-56

Palenzuela, N (ed) (1998) Extrañezas insulares, Centro Atlántico de Arte Moderno: Las Palmas de Gran Canaria

----- (2014) 'Entre Horizontes Insulares/Among Insular Horizons', Third Text v28 n4-5: 345360

Plato (1888) The Timaeus of Plato, Cambridge: R.D Archer-Hind

---- (1956) The Republic of Plato, New York: Oxford University Press

Ribeiro, G (2006) 'Antropologias mundiais - para um novo cenário global da antropologia', Revista brasileira de ciências sociais v21 n6o: 147-185

Ricoeur, P (200o) La mémoire, le temps, l'oubli, Paris: Seuil

Salgueiro, T and Martinho, S (2014) 'Transferência, recontextualização e ensaio. Notas para a literacia de uma exposição insular' in Pimenta, D, Mendes, M and Cró, S (eds) Endemismos e outras naturezas, Funchal: Museu de Arte Contemporânea: 3-13

Salgueiro, T (2001) 'Paisagem e Geografia', Finisterra, XXXVI n72: 37-53

Suwa, J (2007) 'The Space of Shima', Shima: The International Journal of Research into Island Cultures vı nı: 6-14

----- (2012) 'Shima and Aquapelagic Assemblages', Shima: The International Journal of Research into Island Cultures v6 nı: 12-18 
Nolasco: Azores/Madeira Islandscapes in Art

Valente, A (1999) As artes plásticas na madeira (1910 - 1990) Conjunturas, factos e protagonistas do panorama artístico Regional no século XX, Madeira University Masters thesis: https://digituma.uma.pt/handle/10400.13/251 - accessed 28th January 2019

Walcott, D (1986) 'Pantomime', World Literature Written in English v26 n1: 169-77 